\title{
LIETUVOS EVANGELIKŲ REFORMATŲ BAŽNYČIOS SINODO AKADEMINIO LAVINIMO POLITIKOS NUOSTATOS 1867-1914 M.
}

\section{Arūnas Baublys}

Klaipėdos universiteto Baltijos regiono istorijos ir archeologijos institutas

\begin{abstract}
Anotacija
Lietuvos inteligentijos ir jos konfesiniu grupiu formavimosi aplinkybès XIX a. pabaigoje yra viena aktualių ir mažai tirtu Lietuvos istoriografijos temu. Straipsnyje nagrinejama Lietuvos Evangeliku Reformatu sinodo akademinio lavinimo politikos nuostatu kaita, fiksuota sinodu nutarimuose 1867-1914 metu laikotarpiu, yra sudetine šios problemos dalis.

PAGRINDINIAI ŽODŽIAI: Lietuva, evangelikai reformatai, sinodas, akademinio lavinimo politika.
\end{abstract}

\section{Annotation}

Die Umstände der Bildung der litauischen Intelligenz Entstehung und ihrer konfessionellen Gruppen am Ende des 19. Jahrhunderts ist eines der relevantesten und am wenigsten untersuchten Themen der litauischen Geschichtsschreibung. Der Artikel untersucht die Änderung der akademischen Bildungspolitik der litauischen evangelisch-reformierten Synode, die in den Beschlüssen der Synoden im Zeitraum der Jahren 1867-1914 festgehalten wurde, und ist ein wesentlicher Bestandteil dieses Problems.

STICHWORTE: Die Evangelisch-Reformierten, Litauen, Synode, Akademische Bildungspolitik.

DOI: http://dx.doi.org/10.15181/mtd.v0i7.2312

\section{Ivadas}

Lietuvos reformacinių bažnyčių istorijai, kaip ir pačiai Reformacijai LDK, skirta santykinai nemažai, taip pat ir naujų tyrimų, tačiau dauguma jų sutelkti ties XVI-XVII a. Reformacijos, besikuriančių bažnyčių bei jų ịtakos LDK visuomenei problematika. Vèlesni laikotarpiai, skirti šių bažnyčių, veikiančių konfesinių mažumų sąlygomis, ypač tiriant jų savivaldos institu- 
cijų vykdytą savarankišką politiką, darbų ir autorių gausa pasigirti negali. Tai ypač ryšku kalbant apie XIX a. vidurio ir pabaigos laikotarpic.

Šios publikacijos tyrimo objektas - Lietuvos Evangelikų Reformatų Bažnyčios sinodo jaunimo akademinio lavinimo politikos nuostatos, kurias jis taikè po 1863-1864 metų sukilimo, pagausèjus valstybės represijų, ir pamažu jų atsisakẻ tautinio atgimimo judejimo laikotarpiu bei Pirmojo pasaulinio karo pradžioje.

Tyrimo chronologija. Kaip pirminis atskaitos taškas pasirinkti 1867 metai, siejami su pirmuoju sinodu, kuris sušauktas po sukilimo. Laikotarpis baigiamas Pirmojo pasaulinio karo, kuris ilgam nutraukẻ reguliarų sinodų darbą, pradžia (1914 m.).

Tyrimo tikslas: išnagrinèti ir sistemiškai apibendrinti Lietuvos Evangelikų Reformatų Bažnyčios (LERB) sinodo priimtų nutarimų bei sprendimų, susijusių su akademiniu jaunimo lavinimu, turinį, nustatyti sinodo strateginio veikimo kryptis, tendencijas ir jų pasekmes.

Tyrimo metodai parinkti atsižvelgiant ị naudotus šaltinius: sintetinis, analitinis ir aprašomasis šaltinių analizès metodai, padedantys atsakyti ị tyrimo keltus klausimus.

Šio tyrimo pagrindiniai šaltiniai yra sinodų nutarimai (toliau tekste vadinami sinodalais $-A$. B.), kurie pagal savo svarbą ir reikšmę, atsižvelgiant ị sinodo dalyvių valią, skirstyti ị kanonus ir memorialus. Pagal nusistovèjusią bažnyčios valdymo tradiciją sinodą sudarẻ dvasininkai (pradedant ordinuotais kunigais), bažnyčios distriktų (vyskupijų analogas $-A$. B.) priešsinodinèse sesijose rinkti pasaulietiniai sinodo delegatai ir ịstatymiškai neapibrèžtas nuolatinę balso teisę turinčių sinodo kuratorių, kurie rinkti visuotiniu sutarimu sinoduose iš pasauliečiu iki gyvos galvos, skaičius. Laikotarpiu tarp sinodų susirinkimų bažnyčios vykdomoji valdžia - sinodo kolegija (tuo metu vadinta Vilniaus kolegija - A. B.) užtikrino sinodų sprendimų vykdymą tarpsinodiniu laikotarpiu, nors turèjo teisę esant neatidèliotinoms aplinkybėms veikti savarankiškai, vèliau atsiskaitant artimiausiam sinodui.

Sinodo sprendimai skirstyti ị vadinamuosius kanonus ir memorialus. Sinodo kanonas, priimtas konsensuso būdu, turèjo ịstatyminę galią bažnyčios savivaldos viduje ir buvo privalomas vykdyti. Memorialas - tai potvarkis, 
kurị privalèjo vykdyti bažnytinė administracija, priimtas siekiant spręsti konkrečius praktinius klausimus, nors neretai primindavo senesnius sinodų kanonus ir memorialus, kurie turejo padèti spręsti analogiškas problemas. Taigi sinodo teisinè sistema turejjo ryškų precedentinès teisès požymį.

Sinodų kanonai ir memorialai ne visada preciziškai atskleidžia problemos sprendimo eigą, dažnai nedetalizuoja jos procedūrinių elementų, vis dèlto jie leidžia įžvelgti bažnyčios priimtų pamatinių sprendimų esmę ir suprasti bažnyčios, kurios valią atskleidžia sinodai, strategines nuostatas.

Šio laikotarpio sinodų šaltiniai saugomi Biržų krašto muziejaus „Sėla“ (toliau - BKM „S“) ir Lietuvos mokslų akademijos Vrublevskių bibliotekos Rankraščių skyriuje F-40 (toliau - LMAVB RS).

Tyrimų istoriografija tiriama tematika gana kukli. Su sinodo XIX a. aukštojo mokslo politika susiję vos keli Aldonos Prašmantaitès darbai (Prašmantaitè, 1995; 1996; 2003). Šiose publikacijose išryškejja bendrosios tendencijos (metmenys), minimi autorès parinkti paskiri faktai, leidžiantys suprasti bendrąsias sinodo politikos kryptis, vis dèlto tai ne nuoseklus ir detalizuotas paskirų laikotarpių sinodo politikos vertinimas.

Kitą publikacijų grupę sudaro keliais etapais atlikti Antano Tylos tyrimai, skirti XIX a. lietuvių kilmès studentų studijų geografijai. Nors jo publikacijose gausu faktų apie paskirus studentus (Tyla, 1973; 1980; 1981), nuosekli sinodo aukštojo mokslo politikos problematika beveik nenagrinèta.

\section{Sinodo vykdyta studijų vietų išsaugojimo politika}

Nors reformatai dalyvavo sukilime, dèl aiškiai išreikšto jo konfesinio pobūdžio, kaip nežymi visuomenès dalis ir konfesinè mažuma, sinodo lygmeniu savo nuostatų dẻl sukilimo neišreiškè. Nepaisant to, kaip viso krašto visuomenè, patyrè ne tik sukilimą malšinančios kariuomenès, bet ir krašto administracijos represijų.

Pirmoji informacija apie akademinius reikalus pateikta 1867 metų sinode, tai pirmasis po sukilimo, krašte pasibaigus didžiajai atvirų represijų bangai, sušauktas sinodas. Akademiniams klausimams čia, palyginti su iki sukilimo vykusiais sinodais, skirta nedaug demesio. Sinodas nagrinėjo tik pačius ak- 
tualiausius, neatidèliotinus klausimus. Vilniaus kolegija susirinkusiems sinodalams referavo, kad tarpsinodiniu laikotarpiu, kuris tęsèsi daugiau kaip penkerius metus, valstybès potvarkiu negrižtamai ir visiems laikams nutrauktas ypatingos 200 rublių dydžio iždo stipendijos Dorpato (dabar Estija, Tartu - A. B.) universitete teikimas (MAB F40, 1026, 1867, Mem. 12, L. 68). Iš sinodo šaltinių neaišku, ar tai buvo viena iš šešių, ar visos nuo 1824 metu sinodo žiniai skirtos stipendijos Dorpato universitete, turejjusios kompensuoti dèl ịvairių priežasčių prarastas studijų Europos universitetuose galimybes, žlugus Abiejų Tautų Respublikai (Baublys, 2006).

Svarbiausia šio sinodo išdava, aptariant akademinio lavinimo klausimus, paskiru memorialu pakartota 1846 metų IV kanono nuostata, pabrěžianti, kad dèl aukštojo mokslo pats sinodas nedaro (nepritaria $-A$. B.) jokių pokyčiu (MAB F40, 1026, 1867, Mem. 106, L. 80). Tokia sinodo laikysena atskleidè, kad jis nesutinka su krašto administracijos vykdomais pokyčiais ir nesiruošia jiems aklai pritarti. Deja, sinodo nutarimų dokumentuose ištisus du dešimtmečius strateginiai studijų organizavimo klausimai, išskyrus įvardytus duomenis apie sinodo auklètinius, kuriems skiriamos stipendijos, bei vietų universitetuose rotavimą, nesvarstyti.

Reikia manyti, kad greičiausiai buvo panaikinta viena stipendija, nes ir toliau ị šį universitetą studentai buvo priimami, o jau studijavusieji nešalinti, ką rodo 1867 m. sinodo kreipimasis ị Dorpato universiteto rektorių, prašant pasirūpinti teologijos studento Vladislovo Ceraskio sveikata. Kreipimosi tekste universiteto vadovybės prašyta Dorpato universiteto klinikose suteikti V. Ceraskiui reikiamą medicininę pagalbą. Turimomis sinodo žiniomis V. Ceraskio sveikata buvo kritiška - jam grèsè apakimas, todèl jis nedelsdamas nutarè skirti gydymui tiek lèšų, kiek reikès, apie tai informavęs universiteto pareigūnus (MAB F40, 1026, 1867, Mem. 15, L. 69). Turbūt gydymas buvo veiksmingas, nes 1870 metų sinodo kanonuose aptiktas sprendimas V. Ceraskiui, studijuojančiam Dorpato universitete penktus metus, toliau skirti stipendiją studijoms (BKM „S“ 18351/6, 1867, Kan. V, L. 13).

1887 metais atsiskaitydama sinodui už atliktą darbą, Sinodo kolegija (toliau - kolegija) referavo apie Sankt Peterburgo universiteto valdybos pranešimą. Universiteto valdyba pranešè, kad universiteto kuratoriaus vardu $1886 \mathrm{~m}$. 
spalio 31 d. iš ministerijos gautas raštas Nr. 15982, kuriuo ši informavo universitetą, o pastarasis - Vilniaus kolegiją, kad, remiantis Rusijos universitetu ịstatais, nuo šiol stipendijų suteikimo teisè priklauso universiteto valdybai.

Tai reiškè, kad nustoja galioti 1838 metų sausio 18 dienos potvarkis, kuriuo švietimo apygarda sinodo auklètiniams skyrè caro patvirtintas specialias stipendijas. Taigi Vilniaus Evangelikų Reformatų Bažnyčios sinodas prarado jo dispozicijai skirtas valstybès Peterburgo universitete mokamas stipendijas. Jis pavedè Vilniaus kolegijai nedelsiant pradèti spręsti šị klausimą. Kolegija ịgaliota kreiptis ị carą su prašymu dvi turètąsias stipendijas ir toliau palikti tiesiogineje sinodo dispozicijoje. Prašymą sinodas motyvavo tuo, kad remiantis 1883 metų sausio 18 dienos ịsaku sinodo turètos stipendijos gali būti laikomos ne iždo, bet privačiomis jo stipendijomis (MAB F40, 881/1, 1887, Mem. 44, L. 68). Deja, teigiamo sprendimo nesulaukta. Universiteto vadovybė dar kurị laiką toleravo šių stipendijų skyrimo ar jų pratęsimo tvarką studentams reformatams, kurie iki potvarkio ịsigaliojimo nespejo baigti studijų, bet 1887-1889 metų laikotarpiu naujų stipendijų neskyrè.

Panaši situacija susiklostė ir Dorpato universitete, į kurị spręsti stipendiju reformatams išsaugojimo problemą išvyko bažnyčios generalinis superintendentas kun. Konstantinas Močiulskis (Albertas Konstantinas Močiulskis 1826-09-27-1887-11-25). Laikantis susiklosčiusios Bažnyčios tradicijos, jis buvo oficialus visų studentų reformatų kuratorius ir turèjo ịgaliojimus valdžios institucijose atstovauti Bažnyčiai sprendžiant šiuos klausimus. Taigi ne tik turèjo spręsti Dorpato universiteto stipendijų klausimą, siekiant išlaikyti jų skyrimą sinodo žinioje, bet ir vizituoti ten besimokančius bažnyčios stipendininkus, domètis jų akademiniais rezultatais bei gyvenimo sąlygomis (MAB F40, 881/1, 1887, Mem. 42, L. 67). Superintendento misija buvo sẻkminga, jam pavyko išsiderèti, kad universiteto vadovybė išsaugotų teisę skirti savo kandidatams tris iš keturių iki tol buvusių stipendijų. Kadangi K. Močiulskis pats buvo baigęs ši universitetą, jị universiteto vadovybè puikiai pažinojo ir tai gerokai palengvino jo paskutinę sėkmingą misiją: $1887 \mathrm{~m}$. lapkričio 25 d. K. Močiulskis netikètai mirè Vilniuje, sulaukęs 61 metų amžiaus.

Valstybès politika karpant valstybès skiriamas stipendijas vertė sinodą ieškoti garantijų, kad jo studijoms atrinkti kandidatai galètų be didesnių trik- 
džių ar biurokratinių formalumų laiku pradèti studijuoti. Precedentinè sinodo teisè paskatino atnaujinti senaji sinodo sprendimą, kuriuo aukštosiose mokyklose studijuojantys sinodo auklètiniai ir asmenys, kuriems studijoms skiriama, nors ir laikinai, Bažnyčios parama, ją gavę sinodui raštiškai ịsipareigotu baigę universitetą grąžinti jų mokslui išleistus Bažnyčios pinigus. Sinodas akcentavo šio nutarimo juridinių procedūrų svarbą, nes sugrąžintos lèšos, kaip numatyta, turèjo būti panaudotos gabiems nepasiturinčių tẻvų vaikams remti (MAB F40, 881/1, 1887, Mem. 41, L. 67). Ši sprendimą lèmė nepalankios Bažnyčiai aplinkybès.

Kadangi Bažnyčios administravimo praktikoje tai nebuvo naujiena, jos vadovybè, taikydamasi prie situacijos, pasinaudojo sinodinès precedentinės teisès praktika ir, atsižvelgusi ị realias aplinkybes, aktualizavo ankstesnių metų sinodo kanonų sprendimą. Nepaisant sunkios finansinės Bažnyčios padèties, tais pačiais metais sinodas prièmé specialų kanoną, kuriuo nustatyta nauja pašalpų teologijos studijas baigusiems universitetų absolventams skyrimo tvarka. Kanono nutarimu panaikintas iki tol galiojęs sinodo potvarkis, kuriuo vadovaujantis visi teologijos mokslus baigę asmenys galejo iš Bažnyčios gauti 200 rublių dydžio pašalpą, kurią ateityje privalèjo grąžinti dalimis, nenustatant konkrečių terminų.

1887 metų sinodo kanone ịtvirtinta nuostata, kad šios 200 rublių dydžio pašalpos nuo tų metų grąžinti nebereikia, ji priklausys visiems be išimties teologijos mokslus baigusiems asmenims (BKM „S“, 18351/6, 1887, Kan. II, L. 74). Šio sprendimo motyvacijos nepavyko aptikti. Galima tik daryti prielaidą, kad taip sinodas siekẻ paskatinti studijuoti teologiją, nes negrąžinama ịsikurti skirta 200 rublių pašalpa buvo solidus indèlis ị skurdų ką tik mokslus baigusio asmens biudžetą, leidusi jam nesiskolinant ir taip išvengiant palūkanų naštos susitvarkyti savo buities sąlygas naujoje paskyrimo vietoje.

\section{Studijų fondai}

Susiklosčiusi nepalanki ir nestabili situacija finansuojant studijas, ne visada sẻkmingos derybos su universitetų valdybomis verte Bažnyčią ieškoti papildomų studijų finansavimo šaltinių, kad užtikrintų jos lèšomis studijuo- 
jančiụjų studijų tęstinumą. Svarstyta, kaip užtikrinti bent minimalų Bažnyčiai būtinų specialistų rengimą savo (Bažnyčios - A. B.) lèšomis.

Šiame kontekste prisimintos Karaliaučiaus universiteto stipendijos, finansuotos dar iš Biržų ir Dubingių kunigaikščių Radvilų įsteigtų bei tebeveikiančių fondų. 1888 metais Žemaitijos distrikto superintendentas kun. Andrius Kadaras pateike sinodui ataskaitą apie savo vizitą į Karaliaučių, kur jis vyko susipažinti su vis dar veikiančio kunigaikščiu Radvilų ịsteigto stipendijų fondo veikla. Fondo administratorius kunigas teologijos mokslų daktaras dr. Pelke pateikè kunigui A. Kadarui veikiančio fondo dokumentų bylą, duomenis apie esamą ịstatinio kapitalo judejimą ir gaunamas sumas už procentus. Išklausius ataskaitą, distrikto superintendentui A. Kadarui pavesta sinodo vardu iš Karaliaučiaus kunigaikščių Radvilų ịsteigto fondo valdytojo pareikalauti, kad šis perduotų sinodo ịgaliojimus turinčiam superintendentui lèšas, gautas kaip procentai iš apyvartinių fondo įstatinio kapitalo lèšų už praeitus (1887 m.) metus, kuriuos sinodas nusprende panaudoti krašto studentams remti. Tai sudarè ịspūdingą 529 markių ir 6 pfenigų sumą (MAB F40, 881/1, 1888, Mem. 15, L. 83). Prašymas patenkintas.

1889 metais sinodas pareikalavo, kad iš metinių Radvilų fondo palūkanų po kitų atsiskaitymų likusios 422 markių ir 80 pfenigų sumos būtų išmokèta stipendija Karaliaučiaus universitete studijuojančiam sinodo auklètiniui Karoliui Močiulskiui (stipendiją sudarè 200 markių), o likusios 222 markès ir 80 pfenigų pervesta kaip parama Dorpato universiteto studentams (MAB F40, 881/1, 1889, Mem. 11, L. 107). 1890 metų Radvilų fondas vèl skyrè 496 markes ir 96 pfenigus iš gaunamų fondo ịstatinio kapitalo palūkanų. Šị kartą lèšos nepanaudotos, tik apie fondo palūkanų dydị specialiu fondo valdytojo laišku informuotas sinodas (MAB F40, 881/1, 1890, Mem. 7, L. 123).

Tais pačiais 1889 metais sinodas reorganizavo ir sèkmingai veikianti Aniševskio vardo stipendijų fondą, kuris iš gaunamų palūkanų reguliariai skirdavo lèšas trims stipendijoms. Dvi iš jų (kiekviena - 150 rublių dydžio) buvo skiriamos pažangiems gimnazijų moksleiviams remti, viena (300 rublių dydžio) - universiteto studentui. Sinodas savo potvarkiu nutarè, kad nuo 1890 metų šis fondas rems tik studentus. Iš esamo fondo kapitalo, tinkamai ji pertvarkius, nutarta sudaryti tris stipendijas, kurių kiekviena turejjo būti 200 
rublių dydžio (MAB F40, 881/1, 1890, Mem. 19, L. 125). Šis sprendimas radikaliai padidino studijų finansavimo galimybes ir iš dalies kompensavo prarastas sinodui garantuotas valstybės lèšomis stipendijas Dorpato bei Peterburgo universitetuose.

1893 metais sinodas patvirtino Karaliaučiaus universiteto teologijos daktarą kunigą Pelke Radvilų fondo valdytoju (MAB F40, 881/1, 1893, Mem. 4, L. 161). Šis sprendimas ịteisino juridinị sinodo, kaip Radvilų fondo dispozitoriaus, statusą. Iš pirmo žvilgsnio šis sprendimas, rodos, neturẻjo jokios didesnès prasmès, tačiau jau kitais metais paaiškejjo tikroji jo esmè: 1894 metų sinodas kreipési ị Radvilų fondo administratorių kun. dr. Pelkę, prašydamas persiųsti ị Rusijos imperiją 18 tūkst. markių dydžio Radvilų fondo ịstatinị kapitalą, kuris turèjo būti deponuotas už 3,5 \% metinių palūkanų Vilniaus žemès banke ir konvertuotas ị 8 tūkst. sidabro rublių dydžio kapitalą. Sprendimas reiškė galutinị šio fondo perkèlimą i Rusiją. Net kaip fondo palūkanų procentai likusios 485 markès, kurios perkèlus pagrindinị kapitalą liko fondo valdytojo dispozicijoje, turejjo būti panaudotos Karaliaučiuje besimokantiems sinodo studentams šelpti. Sinodo prašymu šie pinigai turẻjo būti pervesti ir pridèti prie pagrindinès ịstatinio kapitalo sumos. Atlikus šias banko operacijas, sinodas pasiunte dr. kunigui Pelke'i pakvitavimą, kuriame nurodyta, kad gavo visas Radvilų fondo lèšas (MAB F40, 881/1, 1840, Mem. 4, L. 175-176).

Istoriografijoje minètas kunigaikščių Radvilų įsteigto fondo perkèlimo iš Karaliaučiaus ị Vilnių faktas neminimas. Galbūt tai praslydo nepastebèta gausioje sinodo kanonų ir memorialų jūroje, kaip ir daugelis kitų su šia konfesinès mažumos istorija susijusių faktų.

Šis sprendimas ne toks paprastas ar nereikšmingas, kaip gali atrodyti iš pirmo žvilgsnio. Biržų ir Dubingių šakos kunigaikščiai Radvilos dejjo daug pastangų, kad apsaugotų Reformatų Bažnyčią nuo agresyvios aplinkos, ypač paaiškejjus, kad Reformacija ir jos šalininkai LDK netaps dominuojančia konfesija. Boguslavas Radvila ir jo duktė Liudvika Karolina čia nemažai nuveikè, dèdami saugiklius, kurie turèjo padèti išsaugoti nuolat atsinaujinantị šios konfesijos ekonomini pagrindą. Vidurinio švietimo (Kèdainių ir Slucko gimnazijos) ir studijų užsienio universitetuose ekonominių galimybių išsau- 
gojimas Bažnyčios mecenatų suvoktas kaip viena esminių Bažnyčios gyvavimo garantijų.

Karaliaučiaus universitetas, nors savo konfesine prigimtimi labiau liuteroniškas, ilgą laiką reformatų sinodo stipendininkams buvo svarbus centras, kur jie ịgydavo vokiečių kalbos ir pamatinių teologijos žinių, kad galètų tęsti studijas konfesiniu požiūriu vertingesnèje aplinkoje. Dėl švietimo sistemos reformų Vokietijoje ir kituose Vakarų Europos ar dèl Rusijos imperijos vykdomos politikos uždraudus vykti studijuoti ị tam tikrus užsienio universitetus Karaliaučiaus universitete studijuojančių Lietuvos Reformatų Bažnyčios studentų, nors gerokai sumažèjo, bet vis dar buvo.

Ar sprendimas perkelti teologijos studijoms skirtas lèšas reiškè, kad pasikeite Reformatų Bažnyčios pozicija šio universiteto atžvilgiu, atsakyti sunku. Vertinant esamą problemos kontekstą pirmiausia krinta $\mathfrak{i}$ akis faktų visuma, peršanti mintị, kad šie veiksmai (fondo perkèlimas ị Rusijos imperiją) nulemti grynai politinių ir praktinių sumetimų, nors ne paslaptis, kad pats Karaliaučiaus universitetas akademiniame Vokietijos pasaulyje nelabai tevertintas. Galime nekvestionuoti šio universiteto, ypač jo lietuvių kalbos seminaro, ir lietuvių kalba besidominčių teologijos profesorių (L. Rėzos ar baltistikos pradininko A. Becenberger'io) svarbos Prūsų Lietuvai, jų veiklos svarbos Rusijos okupuotam lietuvių etnosui, bundančiam tautinès savivokos kontekste, tačiau reformatų konfesinių žinių gausa jis netryško.

Karaliaučiaus universitetas reformatams, nepaisant jo akademinės reikšmės ir indèlio ị šio regiono dvasinès kultūros bei protestantiškų bažnyčiu gyvenimą, negalëjo būti tas vienintelis centras, kuris iki tol buvo fiziškai artimiausias ir gal net kiek teologiškai priimtinas Bažnyčiai universitetas šiame regione.

Jau nuo 1832 metų Rusijos valdžios struktūros, siekdamos apsisaugoti nuo, jų nuomone, pragaištingų minčių plitimo iš Vakarų Europos, dirbtinai varžè galimybę gauti protestantų bažnyčiose dvasininko vietą kitų, išskyrus Dorpato universitetą, teologijos fakultetų absolventams (Stegner, 1993). Taigi ne tik Karaliaučiaus, bet ir kiti Europos universitetai, kuriuose nuo seno skirtos stipendijos Lietuvos Reformatų Bažnyčios studentams, dèl draudimų buvo sunkiai pasiekiami akademiniam bažnyčios jaunimui, be to, dirbtinai menkinti jų diplomai, o tai ribojo būsimos tarnybos perspektyvą. 
Vis dèlto Radvilų stipendijų fondas Karaliaučiuje nejudintas, kol rusų administracijos priimti ịstatymai nutraukè valstybinių (mokamų iš iždo A. B.) stipendijų skyrimą Reformatų Bažnyčios studentams. Šis žingsnis privertė Bažnyčią imtis galbūt žvelgiant iš istorinès perspektyvos ir ne visai adekvačių priemonių, kad turètų galimybę rengti Bažnyčiai akademinį (nors ne patị geriausią konfesinị) išsilavinimą turinčius kunigus savo krašte. Esant tokiai situacijai, tai ịvardyta kaip pagrindinè kunigaikščių Radvilų įsteigto studijų stipendijų fondo perkèlimo iš Karaliaučiaus į Vilnių priežastis.

1897 metais sinodas informuotas, kad Dorpato universiteto taryba, atsižvelgdama ị mažą Reformatų Bažnyčios siųstų teologijos studijoms studentų skaičių, 1896 metų spalio 18 dienos potvarkiu nustatè, kad vietoj iki tol buvusių trijų stipendijų Bažnyčiai palieka tik dvi. Sprendimas motyvuotas ir tuo, kad iki tol skirtos 266 rublių dydžio stipendijos, norint normaliai mokytis, nepakanka. Tačiau tikroji priežastis, kurią tame pačiame rašte nurodè universitetas, buvo 1873 metų spalio 9 dienos Rusijos ministrų kabineto sprendimas, kuriuo reikalauta mažinti Dorpate rengiamų protestantų teologų skaičių. Remiantis būtent šiuo potvarkiu ir panaikinta viena iš trijų stipendijų. Sinodas, atsižvelgdamas ị susiklosčiusias aplinkybes, ịpareigojo Vilniaus kolegiją imtis veiksmų ir išsaugoti bent dvi iš buvusių trijų stipendijų Dorpato universiteto Teologijos fakultete (MAB F40, 881/1, 1897, Mem. 15, L. 209). Kokie tai turejo būti veiksmai, sinodo potvarkyje nenurodoma.

Nors studijų finansavimo galimybės sèkmingai padidintos, reorganizavus Aniševskių fondą ir Karaliaučiaus stipendijų fondą perkèlus ị Vilnių, sinodas ir toliau griežtino studijų sąlygas jo lěšomis studijuojantiems jaunuoliams. 1898 metais jis prièmè svarbų sprendimą, kuriuo nutarta, kad mažèjant studijoms skiriamų lěšų, kiekvienas sinodo stipendininkas, baigęs studijas, privalo sugrąžinti tą pinigu sumą, kuri buvo skirta jo išsilavinimui (MAB F40, 881/2, 1898, Mem. 8, L. 4). Sprendimas, nors ir patvirtintas tik kaip sinodo memorialas, nustate, kad šią taisyklę numatoma taikyti atbuline data visiems, kurie studijavo Bažnyčios lèšomis, pradedant maždaug 25 metais nuo šio potvarkio ịsigaliojimo. Potvarkis netaikytas tik tiems, kurie baigę studijas iškart pradèjo dirbti dvasininkais bažnyčiose. Vykdant ši sprendimą, už studijas privalèjo susimokèti visi, kurie mokèsi Bažnyčios lěšomis pradedant 1873 metais. Sunku pasakyti, ar minèta data pasirinkta speci- 
aliai, bet ji sutapo su šiame darbe jau minèto tais pačiais metais priimto Rusijos ministrų kabineto potvarkio, kuriuo įsakyta mažinti Dorpato universitete studijuojančių protestantų teologų skaičių, prièmimo data.

1904 metais sinodas pakoregavo $1898 \mathrm{~m}$. memorialo nuostatas ir nutare, kad sudarant paskutinių 25 metų sinodo stipendininkų sąrašą i jị netraukiami asmenys, tuo metu dirbę dvasininkais, kolegijos nariais ar sinodo kolegijos kanceliarijos darbuotojais (MAB F40, 881/3, 1904, Mem. 23, L. 46). Šiuo sprendimu sinodalai suderino atsiskaitymo už universitetines stipendijas tvarką, o bažnyčios tarnautojai atleisti nuo studijų lešų grąžinimo prievolès.

Siekdamas papildyti studijoms skirtų fondų ịstatinị kapitalą lèšomis ir taip ne tik padidinti pačias stipendijas, bet ir jų skaičių, 1903 metais sinodas nutare imtis senų, laiko išbandytų, bet jau gerokai primirštų priemonių, kurios būtų galejusios pagerinti situaciją. Nutarta atgaivinti tikslinių kolektų rinkimo tvarką, kai vykstant sinodams rinktos laisvanoriškos piniginès aukos ir už tuos pinigus pirkti banko vertybiniai popieriai, kurių duodamas pelnas igalintų ne tik išlaikyti Bažnyčios studentus, bet ir papildytų studijų fondų kapitalą, kaip tikejjosi sinodas, stabiliomis ịplaukomis (MAB F40, 881/3, 1903, Mem. 42, L. 32). Šiuo sprendimu tam tikra prasme grižta prie XVI-XVIII amžiais buvusios tikslinių kolektų tradicijos, kai surinktos lèšos galëjo būti panaudotos tik tiems tikslams, kurie deklaruoti renkant aukas. Tradicijos atnaujinimas buvo sveikintinas reiškinys, nes vykdant panašias akcijas tikintieji galejo parodyti ne tik savo sąmoningumą, bet ir paremti jiems patiems aktualius projektus. Tai buvo svarbiausia, nes tik pačių žmonių asmeninis dalyvavimas vykdant projektą laidavo nuolatinị bažnytinès visuomenès aktyvumą, kartu ir jos dalyvavimą sprendžiant Bažnyčiai aktualius klausimus bei teikè asmeninio dalyvavimo ir asmeninio įnašo pojūtị, kuris veikè lyg dopingas, stimuliuodamas Bažnyčios narių atsakomybę už jos ateiti.

1904 metais sinodas pakoregavo Aniševskių stipendijų fondo įstatus ir nustatè, kad iš jo tuo metu sukaupto įstatinio kapitalo toliau universitetų studentams bus skiriamos ne trys, bet penkios stipendijos (MAB F40, 881/3, 1904, Mem. 26, L. 47). Nors sprendime konkreti stipendijos suma nenurodyta, reikia manyti, kad jis priimtas pagerejus šio fondo finansiniams reikalams ir padidinus studentams skiriamų stipendijų skaičių. 
Lygiagrečiai visiems pokyčiams, kurie vyko Rusijoje ir lemė valstybės nuostatas paskiriems jos gyventojų socialiniams sluoksniams, panašūs procesai vyko ir Reformatų Bažnyčioje. 1904 metais sinodas konstatavo, kad kasmet vis daugejja prašymų skirti akademines stipendijas gimnazijas baigusioms merginoms. Nesant specialių tam reikalui skirtų fondų, sinodas pavedẻ Vilniaus kolegijai atidžiai išstudijavus stipendijų fondų veiklą, surasti lěšu merginų lavinimui ir pateikti savo pasiūlymus kitų, t. y. 1905 metų, sinodui (MAB F40, 881/3, 1904, Mem. 61, L. 56).

Prièmus šị sprendimą, sinodas vèl prisiminè savo istorinius stipendiju fondus. 1904 metais sinodalai pavedè generaliniam superintendentui kunigui V. Mieškovskiui, susisiekus su Karaliaučiaus universiteto Senatu, gauti fundacijos, kuria Liudvikos Karolinos Radvilaitès iniciatyva 1687 m. rugpjūčio 26 d. ịsteigtos trys stipendijos alumnams iš Lietuvos Karaliaučiaus universitete išlaikyti, kopiją (Łukaszewicz, 1842).

Ši informacija atskleidžia, kad, be Radvilų fondo, kurio lěšos jau pervestos iš Karaliaučiaus ị Vilnių, sinodas turejo dar ir kitą kunigaikščių Radvilų palikuonių įsteigtą stipendijų fondą. Šios stipendijos, sinodo manymu, neva turejjo būti skirtos reformatų studentams, kilusiems iš to meto vakarinių Rusijos imperijos gubernijų (MAB F40, 881/3, 1904, Mem. 77, L. 59).

Karaliaučiaus universiteto Senatas kunigui V. Mieškovskiui atsiuntė neigiamą atsakymą, kuriame pažymėjo, kad nei fondo steigiamojo rašto originalo, nei jo kopijos universitetas neturi. Tai pranešta 1905 metų sinodui (MAB F40, 881/3, 1905, Mem. 44, L. 70). Mažai tikètina, kad universiteto archyvas tokio dokumento neturèjo, nes laikas parodé, kad diskusija dèl fondo atnaujinta XX a. pradžioje. Visiškai ịmanoma, nors tai tik prielaida, kad pasimokę iš Radvilų fondo likimo, visų kortų universiteto senatoriai ir administracija atskleisti neskubejo. Kita vertus, galbūt toks atsakymas sinodą patenkino, nes daugiau nutarimų šiuo klausimu nepriimta.

Ir toliau pagrindiniu studijų finansavimo šaltiniu liko pačios bažnyčios sukauptos lèšos. Jos šiam reikalui kauptos sèkmingai. 1908 metais kolegija savo ataskaitoje sinodui pažymėjo, kad stipendijų fondas nuolat auga. Tu metų fondo apyskaita atskleide, kad fondo lèšos jau siekè 2700 rublių, kurie investuoti i 4,5\% metinių palūkanų duodančio Vilniaus žemès banko verty- 
binius popierius. Be to, fondo kasoje grynais pinigais buvo dar 238 rubliai ir 92 kapeikos. Sinodas ịpareigojo ir toliau didinti šio fondo kapitalą vykstant sinodui renkant laisvanoriškas aukas, kaip nutarta 1903 metų 42-uoju memorialu (MAB F40, 967, 1908, Mem. 8, L. 2).

Sèkminga stipendijų fondo veikla davė apčiuopiamų rezultatų. 1908 metais iš šio ir Aniševskių vardo fondų vienkartinès pašalpos forma skirtos stipendijos dešimčiai Reformatų Bažnyčios studentų. Jos siekè nuo 150 iki 50 rublių dydžio. Bendra skirtų stipendijų suma - 900 rublių. Pažymėtina, kad stipendijų skyrimas fiksuotas tik memorialo sprendimu, nenurodant kuriame universitete ar kitoje aukštojo mokslo įstaigoje besimokantiems asmenims jos skirtos (MAB F40, 967, 1908, Mem. 63, L. 12-13).

Sprendimas griovė nusistovejusią studijų finansavimo tradiciją. Šios pašalpos-stipendijos negarantavo nuolatinès sinodo finansinès paramos ją gavusiems asmenims, o jų skyrimas nereiškè, kad Bažnyčia apsiima visą laiką padèti tiems asmenims, kol jie baigs studijas, mokèti už jų studijas. Parama, teikiama paskolos būdu, Bažnyčios veikiau inicijuota kaip savotiška studiju paramos kasa, kurios buvimas igalino neturtingus, bet ir gabius valstiečių ar miestelėnų luomų jaunuolius, kuriuos rèmé giminės ir artimieji, igyti akademinị išsilavinimą. Šių stipendijų-pašalpų skyrimas iš esmès buvo nauja studijų rèmimo forma, nulemta pokyčių, tuo metu dinamiškai ir negrįžtamai vykusių Lietuvos visuomenèje.

Sinodas neatsisakè iki tol buvusios tradicinès studijų rėmimo tvarkos, bet gerokai sumažino tradicinių visą išlaikymą garantuojančių stipendijų skyrimą universitetuose, taip skatindamas studijų finansavimo sąnaudas nuimti nuo bažnyčios pečių ir perduoti patiems kandidatams ị studentus bei jų šeimų nariams. Toks gana radikalus posūkis studijų rėmimo politikoje nereiškè, kad sinodas, kartu ir visa Bažnyčia, atsisako savo tradicinès studijų rèmimo politikos ar kad Bažnyčios vadovybė nebeteikia reikšmès aukštajam mokslui. Žengti ši žingsnị paskatino mūsų jau minèti studijų finansavimo politikos pokyčiai. Akivaizdu, kad jau seniai studijų finansavimas turèjo būti ne tik Bažnyčios reikalas, nes mažèjančios finansinès galimybès netenkino didejančios konfesinès paramos poreikio. Bažnyčia negalejjo tapti labdaros organizacija, kuri remia visus tikinčiuosius, pageidaujančius igyti aukštaji išsilavinimą. Ši 
tendencija buvo ypač pavojinga, nes lėmè nuostatos, kad Bažnyčia tampa atsakinga už reformatų bendruomenès narių išsilavinimą, o pati bendruomenė užima tik pasyvios reikalautojos poziciją, formavimąsi. Iૃvykę pokyčiai leido Bažnyčios vadovams diferencijuoti akademinio lavinimo paramą ir už bažnyčios lèšas rengti tik specialistus, kurių reikia jai pačiai. Tuo tarpu kitiems ji deklaravo paramą, atsižvelgiant ị esamas galimybes.

Idomu, kad tarp tų dešimties stipendininkų, iš dalies remiamų Bažnyčios lěšomis, buvo ir viena mergina - Sofija Sakalauskaitè, kuri bent jau iš pirmo žvilgsnio glaudžiais giminystès saitais nebuvo tiesiogiai susijusi su kuria nors kunigų ar bažnyčios vadovų pasauliečiu šeima (MAB F40, 967, 1908, Mem. 63, L. 12-13). Kol kas tai pirma konkrečiai ịvardyta reformatų konfesijai priklausiusi moteris, pradejjusi studijuoti neįvardytoje aukštojoje mokykloje.

Stipendijų fondas sparčiai augo. 1909 metais kolegija savo ataskaitoje sinodui nurodè, kad stipendijų fonde yra 5200 rublių, kurie, kaip ir pernai, investuoti ị Vilniaus žemès banko vertybinius popierius su metinėmis 4,5\% palūkanomis. İ kasą grynais pinigais įnešti 155 rubliai ir 53 kapeikos. Konstatavus fondo būklę, pakartota nuostata jị didinti, ịtvirtinta 1903 metų sinodo nutarimu (MAB F40, 967, 1909, Mem. 8, L. 19). Fondo lèšų augimas puikiai iliustruoja ne tik šios konfesijos požiūrị i aukštojo mokslo svarbą ar savo konfesijos gretų išsilavinusiais žmonèmis, kurių reikejjo pačios bažnyčios egzistavimui, papildymą, bet akivaizdžiai parodo, kad jau tuo metu bažnytinė visuomenė aiškiai buvo konstatavusi nacionalinès konfesinès inteligentijos, kurios dèka buvo galima tikètis išlaikyti ne tik tikèjimą ir Bažnyčią, bet kuri, matyt, apskritai suvokta kaip bažnytinès visuomenès gyvybingumo varomoji jèga, jos atsinaujinimo garantija, svarbą.

1909 metais sinodas iš savo fondo parèmè jau 13 studentų, jų studijų stipendijoms skirdamas 925 rublius. Reikia pažymèti, kad sinodo disponuojamų studijų fondo ir Aniševskio vardo fondo išmokèta suma prilygo praeitu metų sumai, tie 25 rubliai, kuriais viršyta praeitų metų suma, skirti ne sinodo, bet iš Vilniaus parapijos surinktų lèšų, jie paskirti Steponui Prževlockiui prie sinodo skirtos 50 rublių sumos. Šios stipendijos skirtos studijoms imperijos universitetuose ir kitose aukštosiose mokyklose nenurodant, kur koks studentas konkrečiai studijuoja (MAB F40, 967, 1909, Mem. 51, L. 29). 
I šị stipendininkų sąrašą neįtrauktas vieneriems metams studijuoti teologiją paskirtas Oskaras Lenertas. Šis paskyrimas patvirtintas sinodo kanonu, tam reikalui skirtos lëšos paimtos iš Radvilų fondo. Todèl skaičiuojant bendrą sinodo léšomis 1909 metais išlaikytų studentų skaičių reikia nurodyti ne 13, bet 14. Toks nemažas studentų skaičius vertė griežtai laikytis dar 1905 metais 21-uoju memorialu nustatytos tvarkos, pagal kurią studijas baigę asmenys privalejo iš savo gaunamų atlyginimų pamažu grąžinti jų studijoms skirtas bažnyčios lèšas. Sinodas ịpareigojo kolegiją informuoti jị apie grąžintas pinigų sumas ir apskritai griežčiau kontroliuotu šį procesą (MAB F40, 967, 1909, Mem. 59, L. 31).

Nors 1910 metais stipendijų fondo lèšų pagausejjo, augimas nebebuvo toks staigus kaip 1909 metais. Vilniaus žemès banke vertybiniais popieriais paversta suma su tais pačiais 4,5\% metinių palūkanų jau sieke 5600 rublių. Fondo kasoje ataskaitos pateikimo laiku grynų pinigų buvo 313 rublių ir 38 kapeikos. Fondo kaupimas nesustabdytas ir sinodas vèl tradiciškai paragino jị didinti laisvanoriškomis aukomis (MAB F40, 967, 1910, Mem. 8, L. 34). Tais metais jis finansavo 14-os studentų studijas, skirdamas iš sinodo stipendijų ir Aniševskių fondų 950 rublių. Ši suma 25 rubliais viršijo praeitų metų tam pačiam reikalui asignuotą sumą, nors, kaip minèta, realiai ta suma viršyta 50 -ia rublių. Nepaisant to Viktoro Rolniko ir Teltovto prašymai liko nepatenkinti, nes sinodas tam pritrūko lèšu (MAB F40, 967, 1910, Mem. 31, L. 38).

1911 metais vèl pastebimas ryškus stipendijų fondo lèšu gausèjimas. Tais metais fondo pagrindinis kapitalas Vilniaus žemès banke jau siekè 6100 rublių (MAB F40, 967, 1911, Mem. 8, L. 51). Nepaisant tokio, rodos, spartaus lěšų kaupimo tempo, sinodo budrumas prižiūrint skirstomas pinigų sumas nesumažejo. Pasitaikius atvejui, kai stipendija išduota asmeniui, kuris nebesimokè ir nebuvo ịtrauktas ị mokymo ịstaigos sąrašus, sinodas nutarè, kad nuo tų metų sinodo stipendijos bus skiriamos tik tada, kai pretendentai ị jas prieš skirstymą pristatys mokymosi ịstaigos pažymą, kad jie tikrai yra tos įstaigos besimokančiujjų sąrašuose. Be to, nutarta, kad ši dokumentą tam tikrais atvejais gali pakeisti ir žinomo bei garbingo bažnyčios nario liudijimas (MAB F40, 967, 1911, Mem. 52, L. 59). Tokios priemonès buvo būtinos, nes pretendentų, norinčių gauti sinodo paramą, skaičius nuolat augo, tad daugejjo 
ir galimų apsirikimų bei klaidų skirstant stipendijas. Pagerèjus bažnyčios finansinei padėčiai, vèl atnaujintas paskolų studentams skyrimas. Ši praktika, plačiai taikyta XIX amžiaus pradžioje, esant sudètingai Bažnyčios finansinei padèčiai buvo apmirusi.

1911 metais su prašymu paskolinti 100 rublių i sinodą kreipėsi teologijos studentas Adomas Šernas. Sinodas sutiko jam suteikti paskolą iš Bažnyčios ekonominio draudimo fondo su sąlyga, kad jis per pirmuosius šešerius metus po studijų baigimo grąžins sinodui pinigus su 4,5 \% banko palūkanų. Už šią paskolą finansinę garantiją sinodui asmeniškai turejjo pateikti net trys dvasininkai: superintendentas kun. M. Jastržembskis, kun. P. Jakubėnas ir kun. dr. K. Kurnatauskas. Visi jie įsipareigojo lygiomis dalimis grąžinti studento A. Šerno skolą, jam pačiam to neatlikus (MAB F40, 967, 1911, Mem. 54, L. 59). Iš pirmo žvilgsnio tokia griežta tvarka ir ịsipareigojimai, kuriuos teko prisiimti net trims dvasininkams, atrodo biurokratiški ir labiau tinkami bankui nei Bažnyčiai. Vis dèlto šią tvarką lèmė Bažnyčios turima patirtis: tokios skolos kartais labai lètai ir sunkiai grąžintos. Kitas šią procedūrą lèmęs momentas Bažnyčia, kaip banko kliente, turèjo paisyti esamų bankininkystès įstatymų ir tvarkos. Kiek stipendijų paskirta 1911 metais, sunku pasakyti, nes vienintelio išlikusio 1911 metų sinodo memorialų originalo egzemplioriuje, kuris saugomas Mokslų akademijos Bibliotekos rankraštyne, trūksta vieno lapo, kuriame buvo stipendininkų sąrašas. Išlikusi šio sąrašo pradžia, kurioje - tik 14-os studentų pavardès. Jų stipendijoms skirta 900 rublių suma (MAB F40, 967, 1911, Mem. 61, L. 61). Atsižvelgiant ị kai kurias šaltinio sudarymo ypatybes, tas faktas, kad paskutinè suliniuoto popieriaus lapo, kuriame rašyti memorialai, eilutė liko neužpildyta, atskleidžia, kad sąrašas galutinis ir jokio tęsinio nėra. Nes visuose kituose memorialų puslapiuose su panašiais įrašais kruopščiai užpildytos visos laisvos eilutès nuo lapo viršaus iki pat apačios.

1912 metais sinodo stipendijų fondo lèšos Vilniaus žemès banke išaugo iki 6400 rublių. Jis ir toliau pildytas tomis pačiomis sąlygomis kaip ir anksčiau. Tais metais fondo kasoje grynais pinigais, kaip nurodè savo ataskaitoje kolegija, buvo 30 rublių ir 89 kapeikos (MAB F40, 967, 1912, Mem. 7, L. 68). Išduodant stipendijas ir toliau vadovautasi 1911 metų 53-iojo memorialo nuostatomis, kurios reikalavo, kad norintis gauti sinodo stipendiją 
kandidatas pristatytų dokumentą, liudijanti, jog jis tikrai mokosi vienoje ar kitoje mokslo įstaigoje.

Iš stipendijų ir Aniševskių fondų 1912 metais skirta net 1200 rublių stipendijoms, kurios išmokètos keturiolikai studentų (MAB F40, 967, 1912, Mem. 67, L. 79). Suma išties ịspūdinga, gerokai viršijusi iki tol buvusias. Vis dèlto sinodas sulaukè tam tikros kritikos dèl bendros stipendijų skirstymo tvarkos. Sinodo delegatai kritikavo tai, kad skirstant stipendijas neatsižvelgiama ị stipendijas ar pašalpas norinčių gauti pretendentų turtinị cenzą. Tokia tvarka kèlè teisètą sinodalų pasipiktinimą, mat viešumon ėmė kilti faktai, kad dažnai pašalpos skirtos net tiems studentams ar moksleiviams, kurių tẻvai gyveno geriau, ar suteikiamos keliems vienos šeimos vaikams, tuo tarpu ne tokios turtingos šeimos negaudavo paramos net vienam vaikui išmokslinti. Sinodas nutarè su šia situacija nesitaikstyti. Nutarta, kad pirmumo teisę gauti stipendiją ar paramą turès neturtingų šeimų vaikai (MAB F40, 967, 1912, Mem. 74, L. 82).

Kolegija, administruodama Bažnyčios reikalus laikotarpiu tarp sinodų, sudarydavo kandidatų ị studentus sąrašus, kurių pagrindu jie gaudavo stipendijas ir galèdavo sumokèti už mokslą. Paprastai tokie prašymai buvo pateikiami sinodo vardu ir svarstomi per sinodo posèdžius, vèliau persiunčiami Vilniaus kolegijai vykdyti. Tarp sinodo dokumentų yra tokio tinkamai surašyto dokumento pavyzdys - 1913 metų Pernaravos gimnazijos absolvento Jono Variakojo Vilniaus kolegijai pateiktas prašymas įtraukti ji ị kandidatu gauti stipendiją teisès studijoms Peterburgo universitete sąrašą (MAB F40, 967, 1913, Mem. 7, L. 86). Kitas tokios Vilniaus kolegijos veiklos pavyzdys yra ataskaita apie paskirto ị Karaliaučių studijuoti dar 1912 metais Škrabalio neatvykimo studijuoti priežastị: sinodui pranešta, kad studentui sutrukdè išvykti tai, kad jis dar nebuvo atlikęs karo prievolès (MAB F40, 967, 1913, Mem. 8, L. 86).

Be stipendijų, Vilniaus kolegija tvarkè kelionpinigių skyrimo teologijos studentams reikalus. Šie pinigai buvo skiriami kelionei ị sinodą arba universitetą iš nenumatytų išlaidų asignavimų sumos, kurią kasmet kolegijos dispozicijai skirdavo sinodas. Pavyzdžiui, 1913 metais teologijos studentui Žemaičiui skirti 25 rubliai kelionei ị sinodo susirinkimo vietą, o teologijos 
studentui Kregždei skirta 50 rublių kelionei ị universitetą (MAB F40, 967, 1913, Mem. 50, L. 96). Kolegijos teikimu, sinodas atidejjo teologijos studento Fibicho paskolos, paimtos pragyventi Karaliaučiuje (164 rb ir 94 kp), gražinimą dar dvejiems metams (MAB F40, 967, 1913, Mem. 53, L. 96). Be to, tam pačiam studentui paskirta dar 100 rublių, kad galètų susimokèti už studijas Karaliaučiaus universitete (MAB F40, 967, 1913, Mem. 54, L. 96).

Stipendijų ir pašalpų mokslui skyrimas nuolat kontroliuotas Vilniaus kolegijos. Remdamasi 1911 metų 52-53 memorialų nutarimais kolegija pranešè sinodui apie visus neatitikimus tiems nutarimams (MAB F40, 967, 1913, Mem. 27, L. 92).

1913 metais kolegija pateikè sinodui ataskaitą apie stipendijų fondo situaciją. Fondo pagrindinis kapitalas buvo išaugęs iki 6700 rublių ir saugotas tomis pačiomis sąlygomis Vilniaus žemès banke. Fondo kasoje buvo 42 rubliai ir 60 kapeikų grynujų pinigų (MAB F40, 967, 1913, Mem. 33, L. 93).

1913 metais sinodas skyre paskutines stipendijas prieškario laikotarpiu. Tu metų Aniševskio vardo fondo pagrindinis kapitalas banke jau sieke 15 tūkst. rublių. Iš šio ir stipendijų fondų palūkanų procentų skirta 13 stipendijų, kurių bendra suma - 1120 rublių (MAB F40, 967, 1913, Mem. 64, L. 98-99).

1913 metais sinodo stipendininkų studijų galimybės pasipildẻ dar vienu finansiniu šaltiniu. Tais metais sinodas atskiru kanonu prièmè nutarimą, kuriuo remiantis mirusio Peterburgo vokiečių evangelikų-reformatų kunigo, bažnyčios istoriko H. Dalton'o testamentu vienam Vilniaus sinodo auklètiniui skirta stipendija studijuoti Halès universitete. Sinodas savo sprendimu pavedè Vilniaus kolegijai susisiekti su Peterburgo vokiečių evangelikų-reformatų igaliotuoju atstovu ir sutvarkyti būtinus formalumus, kad studijuoti galètų vykti sinodo paskirtas Konstantinas Kregždè. Nebūdamas tikras, kad stipendija, kol bus tvarkomi formalumai, neatiteks kitam, galbūt Peterburgo kandidatui, sinodas dèl viso pikto nutare K. Kregždei rezervuoti studijų vietą Karaliaučiaus universitete (BKM „S“ 18351/6.1913, Kan. IV, L. 183).

Šios stipendijos skyrimas svarbus ne tik tuo, kad sinodo auklètiniams atsirado dar viena studijų užsienyje galimybè. Svarbiausia buvo tai, kad Reformatų Bažnyčia šią stipendiją gavo iš asmens, kuris visą savo gyvenimą spaudos draudimo sąlygomis padejo spausdinti religinio turinio lietuviškus 
raštus, kurie neleido užgesti ne tik religinei, bet ir lietuviškumo sąmonei Lietuvos Reformatų Bažnyčioje.

1914 metais atskiru kanonu priimtas nutarimas dèl Jono Balčiausko testamentu palikto turto pagrindu įsteigto fondo. Sinodo kolegija paskelbė pranešimą apie provizoriaus, sinodo kuratoriaus Jono Balčiausko testamentu užrašytą 10 tūkst. rublių sumą, kuri turèjo sudaryti stipendijų fondo pagrindą. Aukštosiose mokyklose studijuojantiems studentams numatyta skirti keturias dešimtąsias nuo 10 tūkst. rublių sumos gaunamų metinių palūkanų sumos. Tuo atveju, jei tam reikalui skirta suma negalejo būti išnaudota, ji turèjo būti paskirta kitais metais. Ją panaudoti kitiems tikslams griežtai draudè fondo taisyklès. Stipendijos turèjo būti skiriamos aukšto moralès lygio gerai besimokantiems evangelikų-reformatų ir Romos katalikų tikẻjimo abiejų lyčių asmenims. Pirmumas skiriant stipendijas numatytas tik testamento autoriaus giminaičiams (BKM „S“ 18351/6, 1914, Kan. IX, L. 189).

Šis testamento valia įsteigtas fondas savotiškai užbaigia Evangelikų Reformatų Bažnyčios sinodo priimtus nutarimus dèl aukštojo mokslo studijų finansavimo 1867-1914 metų laikotarpiu. Nors šiuo fondu praktiškai pasinaudoti neteko, nes prasidejęs Pasaulinis karas ir jam pasibaigus ịvykęs bolševikinis perversmas sunaikino ne tik imperiją, bet ir niekais paverte visas santaupas, kurios saugotos bankuose, jo ịsteigimas ir kai kurie jo naudojimo aspektai yra svarbūs. Pirmiausia tokio masto konkretaus asmens fondo ịsteigimas nedviprasmiškai byloja, kad aukštojo mokslo svarba šios konfesijos visuomenès suvokta ir įvertinta gerokai anksčiau nei liuteronų ar katalikų. Tai, kad reformato, sinodo kuratoriaus, įsteigtas fondas numatè remti abieju konfesijų - reformatų ir katalikų - jaunimą paritetiniais pagrindais, byloja, jog šios konfesijos elito atstovai puikiai suvoke inteligentijos vaidmenį krašto viešajame gyvenime ir sugebejjo peržengti konfesines ribas. Kitaip tariant, krašto reikalai buvo svarbesni už religinius nesutarimus, nuoskaudas, patirtą neteisybę ir persekiojimus, kurių metams bėgant nemažai būta. 


\section{Sinodo politika dėl universitetų absolventų}

1891 metais sinodas kanonu ịteisino naujus sinodo ir teologijos mokslus baigusių jo auklètinių tarpusavio santykius. Nutarta, kad sėkmingai teologijos studijas baigę asmenys automatiškai neiggyja teisès iškart gauti mokamą tarnybą Bažnyčioje, jei tuo metu nèra laisvos vietos arba sinodas nutaria, kad jie dèl tam tikrų priežasčių netinkami užimti garbingos dvasininko vietos. Susiklosčius tokiai situacijai, minèti asmenys sinodo sprendimu gali būti atleisti nuo atitarnavimo sinodui už jiems skirtą stipendiją. Taip jie ịgyja teisę laisvai pasirinkti užsièmimą ir gyvenimo būdą. Atsiradus laisvai vietai, sinodas pasiliko sau teisę šiems asmenims ją pasiūlyti. Nutarta, kad asmeniui savo noru pareiškus nepageidavimą atitarnauti Bažnyčiai, sinodo sprendimu jis privalo grąžinti visą jo išsilavinimui universitete Bažnyčios išleistą pinigų sumą (BKM „S“ 18351/6, 1891, Kan. III, L. 91).

Praktinį kanono taikymą puikiai iliustruoja 1905 metų kanonas „Apie stipendininkus“, kuriame sakoma, kad Slucko gimnaziją baigusị Adomą Šerną jo prašymu sinodas skiria ị tuo metu Dorpato universiteto Teologijos fakultete laisvą studijų vietą. Kartu pabrèžta, kad sinodas jo atžvilgiu nesiima jokių i̊sipareigojimų ir negarantuoja, kad jam baigus studijas bus iš karto įšventintas ị dvasininkų luomą ir gaus darbą, jei tuo metu nebus laisvos vietos (BKM „S“ 18351/6, 1905, Kan. II, L. 148).

Nepaisant tokios griežtos nuostatos, tas pats 1905 metų sinodas paskyrè 70 rublių pašalpą A. Šernui, ketinusiam studijuoti teologiją Dorpate: 20 rublių skirta kelionei i sinodą, 50 - i Dorpatą (MAB F40, 881/3, 1905, Mem. 79, L. 78). Taigi savo veiksmais sinodas paskatino kandidatą ị dvasininko luomą tęsti pasirinktą kelią, tik įspejjo, kad jo pasirinkimas, nepalankiai susiklosčius aplinkybėms, negali garantuoti jam darbo vietos.

Užbėgant už akių galima pasakyti, kad tokia vieta atsirado, tad 1912 metų sinodas prièmè atskirą kanoną, skirtą A. Šerno įdarbinimo klausimui. Sinodas pažymėjo, kad teologijos studentui A. Šernui kitais sinodo metais sèkmingai išlaikius baigiamuosius egzaminus, jis, sinodo pavedimu, Vilniaus distrikto superintendento kunigo M. Jastržembskio bus įšventintas ị diakonus.

Kanonas atskleidè procedūros finansinę pusę: studento kelionei ị jo paskyrimo vietą apmokèti iš pulkininko Otenhauzo fondo palūkanų procentų jam skirta 
100 rublių, iš surinktų aukų fondo, kad galètų baigti universitetą, skirta analogiška 100 rublių suma. Iš Vilniaus parapijos kasos sinodas nutarė jam suteikti 50 rublių kelionei iš Dorpato ị Vilnių apmokèti bei paskyre 100 rublių dydžio butpinigių sumą buto nuomai Vilniuje. 200 rublių dydžio diakono alga jam numatyta jau atvykus ị paskyrimo vietą (BKM „S“ 18351/6, 1912, Kan. III, L. 146).

Studentu idarbinimo baigus studijas universitetuose klausimai detaliau tiriamuoju laikotarpiu negvildenti. Ribotos sinodo galimybès įdarbinti ne teologijos studijų absolventus neleido sinodui plačiau angažuoti, pavyzdžiui, teisès studijas baigusių asmenų dirbti bažnyčios valdymo struktūrose. Teologijos fakulteto absolventai, jei tik jie patys nepareikšdavo noro nedirbti pagal igytą specialybę, įdarbinti, kaip tai iliustruoja ką tik minètas A. Šerno atvejis.

Sinodas, nors skrupulingai laikèsi visų kanonų teisèje numatytų procedūrinių dalykų, kurie fiksuoti sinodo kanonuose, bet ir čia būta nesusipratimų. Kaip pavyzdi galima paminèti faktą, kad remiantis 1882 metų antruoju kano$\mathrm{nu}$, visiems teologijos mokslus baigusiems studentams sinodas nutarė mokèti vienkartinę negrąžinamą 200 rublių dydžio pašalpą. Dėl kažkokių aplinkybių tai nepadaryta buvusio studento Konstantino Kurnatausko atveju. Klaida pastebėta tik 1912 metais, ją sinodas nedelsdamas atitaisè išmokẻdamas priklausančią pinigų sumą Kelmès parapijos kunigui filosofijos dr. K. Kurnatauskui (MAB F40, 967, 1912, Mem. 34, L. 73).

\section{Sinodo projektas rengti nacionalinius dvasininkų kadrus Dorpato universiteto Teologijos fakultete, dvasininkų kvalifikacijos tobulinimas}

1906 metais akademiniuose sluoksniuose pasklidus žiniai, kad Dorpato universitete yra galimybė steigti praktinès teologijos katedrą su dèstoma lenku kalba, sinodas tuo susidomėjo ir ịpareigojo Vilniaus kolegiją surinkti tuo klausimu daugiau žinių iš universiteto, be to, susisiekti su Lenkijos Reformatų Bažnyčios konsistorija Varšuvoje. Sinode nuspręsta imtis bendrų neatidèliotinų veiksmų ir įsteigti Dorpate tokią katedrą (MAB F40, 881/3, 1906, Mem. 74, L. 95). 1905 metų revoliuciniai neramumai ši darbą pristabdè, bet nenutraukè.

1907 metais sinodas išklause Vilniaus kolegijos pranešimą, kuriuo informuota, kad Varšuvos konsistorija deda visas pastangas ir supranta, kad būti- 
na gauti katedros steigimo leidimą. Šioje situacijoje sinodas pavedè Vilniaus kolegijai koordinuoti savo veiksmus su Varšuvos konsistorija ir savo potvarkiu pastarajai tuo klausimu pavedè kreiptis ị švietimo ministeriją (MAB F40, 881/3, 1907, Mem. 51, L. 106).

Svarbus žingsnis, siekiant pagerinti studijų kokybę ir universitete įsteigti praktinès teologijos katedrą nacionaline kalba, sinodo žengtas 1908 metais. Pasinaudojęs pretekstu, kad dvasininko vietas Vilniaus evangelikų reformatų sinodo žinioje esančiose parapijose pageidaujantys užimti asmenys, baigę Jurjevo (Dorpato - A. B.) universiteto Teologijos fakulteto studijas, be jokio praktinès teologijos pasirengimo lenkų bei lietuvių kalbomis atvyksta dirbti i parapijas ir gerai nemokèdami šių kalbų praktiškai dirbdami patiria didelị nepatogumą, nuo to kenčia ir pastoracinis darbas, sinodas nutaré, kad Vilniaus kolegijai būtų nedelsiant pavesta pradèti rūpintis valdžios institucijose gauti oficialų leidimą atidaryti Dorpato universiteto Teologijos fakultete Praktinès teologijos katedrą, kurioje būtų dėstoma lenkų ir lietuvių kalbomis (MAB F40, 967, 1908, Mem. 21, L. 4).

Nors prasidejjus politiniam ,atšalimui“ planai liko neigyvendinti, bažnyčių vadovai ir pavieniai pažangūs dvasininkai šios minties neatsisakè. Tai rodo kunigų P. Jakubėno ir K. Kurnatausko 1911 metais sinodui pateiktas svarstyti projektas, kuris nebuvo preciziškai parengtas ir konkretus. Tam tikra prasme ji galima laikyti programiniu dokumentu ateičiai, kurị norėjo iggvendinti jaunoji dvasininkų karta, jai vẻliau, pirmosios Lietuvos Respublikos gyvavimo laikotarpiu, buvo lemta Bažnyčios gyvenime suvaidinti lemiamą vaidmenį. Projekto iniciatoriumi buvo kun. P. Jakubènas, nes ir sinodas savo memorialą, skirtą to klausimo svarstymui, pradeda ịvardydamas šiuo klausimu priimtą savo sprendimą, kaip atsakymą ị kun. P. Jakubėno siūlymus. Projekto esminiu teiginiu jaunas valstiečių kilmès lietuvis reformatų kunigas pasirinko akcentą, kad Bažnyčios religinio gyvenimo vystymasis ir religinès savimonès raida yra glaudžiai susiję ne tik su dvasininkų išsilavinimu, bet ir būtinybe toliau tobulintis, mokytis, neatsiliekant nuo teologijos mokslo pažangos. Taigi Bažnyčios dvasininkams iškeltas iš esmès naujas uždavinys jau ne tik igyti aukštajį universitetinị teologinị išsilavinimą, bet šiuo siūlymu suformuluota užduotis ateityje laisvanoriškai dvasininkams siekti akademinio mokslo laipsnio. Sinodas ši 
siūlymą ịvertino teigiamai. Pritarta, kad išties būtų tikslinga dvasininkus siųsti i mokslines komandiruotes - šalies ir užsienio kultūros bei mokslo centrus. Be to, nutarta sutelkti daugiau lèšu naujoms knygoms ir periodikai sinodo bibliotekoje ịsigyti, kuriomis naudodamiesi tiek dvasininkai, tiek ir Reformatu Bažnyčiai priklausantys pasauliečiai galètų lengviau pažinti mokslo ir dvasinio gyvenimo naujoves. Šiame kontekste sinodas nutarè daugiau dèmesio skirti apskritai švietimui, kad po įvairias mokymo institucijas pasklidę reformatai gautų tinkamą, Reformatų Bažnyčios dvasią atitinkantị išsilavinimą ir auklèjimą. Kadangi sinodas neturèjo tam tikslui būtinų lèšų, kad iškart galètų pradèti minètus projektus igyvendinti, nutare kaip pirmaeilę pareigą sinodalams ir visai bažnyčios visuomenei vis priminti šiuos pasiūlymus ir skatinti juos igyvendinti bei materialiai remti. Savo ruožtu sinodas nutare šiems tikslams panaudoti procentus, gaunamus iš banko už stipendijų fondo depozitus, kaskart paskiru sinodo sprendimu juos skirti mokslinèms komandiruotèms apmokèti (MAB F40, 967, 1911, Mem. 67, L. 64-65).

\section{Paskirtų sinodo stipendijų dinamika 1867-1914 metų laikotarpiu}

Numalšinus sukilimą, vienintelè studijų stipendijos skyrimo galimybè užsienyje sinodui liko Karaliaučiaus universitete. Palyginti su XIX a. pradžia dèl ịvairių draudimų stipendininkų čia buvo nedaug (Baublys, 2006). Vieną stipendiją paskyrus 1870 metais, kita skirta tik 1883 metais. Tik 18861892 metų laikotarpiu, išskyrus 1890 metus, kai stipendijų neskirta, sinodas kasmet šiame universitete skirdavo po vieną stipendiją.

1894 metais pervedus Radvilų fondo ịstatinị kapitalą ị Vilnių ir tas lèšas pradejus naudoti studijoms Rusijos imperijos universitetuose finansuoti, studijos Karaliaučiaus universitete, skiriant sinodo stipendijas, vèl tapo epizodinès: skirtos tik 1899, 1906, 1909 metais (po vieną - A. B.) ir tik 1912 metais dvi Karaliaučiaus universitete, kurios tiriamuoju laikotarpiu buvo paskutinès sinodo iniciatyva šiame universitete skirtos stipendijos. Iš viso tiriamuoju laikotarpiu sinodas Karaliaučiaus universitete skyre 13 stipendijų, kuriomis pasinaudojo 8 asmenys. 
Daugiau stipendijų skirta Peterburgo universitete. Jų skyrimas, atnaujintas 1868 metais, nenutrūkstamai tęsėsi iki 1870 metų: tuo laikotarpiu skirtos penkios stipendijos. 1871-1875 metų laikotarpiu jų neskirta. Stipendijų skyrimą atnaujinus 1876 metais, su nedideliais pertrūkiais 1878, 1879, 1884, 1889, 1895, 1896 ir 1902 m. jos skirtos iki 1905 metų. Pradedant 1888 metais sinodo skirtų stipendijų šiame universitete skaičius sumažejo nuo dviejų iki vienos per metus, o po 1905 m. po vieną stipendiją skirta tik 1912 ir 1914 metais. Iš viso šiuo laikotarpiu Peterburgo universitete skirtos 36 stipendijos, kuriomis pasinaudojo 16 asmenų.

Daugiausia stipendijų skirta Dorpato universitete. Pirmąsias dvi po sukilimo sinodas skyrè 1870 metais, vėliau jų skyrimas atnaujintas tik 1876 metais ir su pertraukomis (1878, 1880, 1881, 1884 ir 1885 metais) vyko iki 1893 metų, kasmet skiriant po tris stipendijas. Po 1893 metų norinčiųų studijuoti skaičius mažèjo, be abejo, tai lèmè ir 1873 m. spalio 9 d. Rusijos ministrų kabineto sprendimas, kuriuo valstybei deklaravus būtinybę mažinti teologijos studentų protestantų skaičių galimybė gauti darbą sumažejo. Taigi 1897 metais stipendijų skaičius sumažèjo iki dviejų. Pradedant 1899 metais stipendijų skyrimas tapo veikiau epizodiniu, nes po vieną skirta tik 1905 ir 1906 metais. Išimtį sudare 1912 metai, kai skirtos dvi stipendijos. Iš viso Dorpate skirtos 45 stipendijos, kuriomis pasinaudojo 20 asmenų.

Tenka konstatuoti faktą, kad aptartu laikotarpiu sinodas savo studentų iš vieno universiteto ị kitą nebekilnojo. Tai lèmé senkantys studijų fondai ir ortodoksiška liuteroniška abiejų teologijos fakultetų Karaliaučiuje ir Dorpate struktūra, realiai teologiniais aspektais viena nuo kitos nedaug tesiskyrusi.

Stipendijų skyrimo dinamika 1867-1914 metų laikotarpiu akivaizdžiai rodo ne tik jų skyrimo mažejimo tendencijas, kilus valstybinių stipendijų naikinimo problemų, kurios išspręstos sukūrus naujus ir perkèlus iš užsienio istorinius fondus, lèšų trūkumo klausimas sinodo naudai išspręstas. Taigi stipendijų skyrimą atnaujinus 1868 metais, jos skirtos iki 1870 metų, vẻliau penkerių metų pertrauka, stipendijų skyrimas atsinaujintas 1876 metais, vis dèlto reguliarus jų skyrimas taip ir neužtikrintas: stipendijos neskirtos 1878 , 1884, 1896, 1902, 1907, 1908, 1910 ir 1911 metais, nors kartais jų skaičius siekè net aštuonias per metus. 1897 metais skirtos trys, 1912 metais - net 
penkios stipendijos rode tam tikrą stipendijų skyrimo dinamikos augimą. Likusiais metais sinodo skirtų stipendijų skaičius neviršijo dviejų per metus.

Nors sinodas tiesiogiai apie kandidatų i studijas skaičiaus mažejimo priežastis neužsimena, tenka prisiminti, kad XIX a. pirmojoje puseje uždarius konfesinę Kẻdainių, o po 1863-1864 metų sukilimo - Slucko reformatų gimnaziją pavertus vietinio pavaldumo mokykla, sinodas prarado galimybę daryti ịtaką vidurinio mokslo programoms, kad tinkamai parengtų kandidatus teologijos studijoms. Tam buvo būtinos nuoseklios ir sisteminès vokiečių, graikų ir lotynų kalbų žinios. Studijų galimybes mažino ir suardytas šimtmečiais nusistovėjęs konfesinių vidurinių mokyklų geografiškai šiai konfesijai patogus tinklas, kurio negalejo atstoti Mintaujos, Rygos, Peterburgo ar Varšuvos gimnazijos. Be to, prisidèjo dar ir minèti valstybès trukdžiai (siekis mažinti protestantų studentų teologų skaičių, draudimai vykti ị užsienị, stipendijų skaičiaus mažinimas, dalinis sinodo studijų finansavimas ir kt.).

Minimuoju laikotarpiu sinodas skyré tris netradicines stipendijas: 1886 metais - aukso medaliu Slucko gimnaziją baigusiam Stanislovui Glovackiui iš Aniševskių fondo 300 rublių dydžio stipendiją, suteikdamas teisę jam laisvai savo nuožiūra pasirinkti ne tik studijuojamą dalyką, bet ir studijų vietą bet kuriame krašto universitete; 1887 metais - iš to paties fondo Mykolui Čiglovskiui stipendiją medicinos studijoms Kijevo universitete; 1913 metais - Konstantinui Kregždei Peterburgo vokiečių reformatų kunigo, imperijos Evangelikų generalinès konsistorijos tarejjo reformatų klausimams iš asmeninių lěšų įsteigtą stipendiją Halès universitete.

Tai galima įvardyti kaip ypač gabaus jaunimo skatinimą siekti akademinio išsilavinimo. Žemiau pateiktoje lenteleje pateiktas sinodo skirtų stipendijų skaičius paskirose aukštosiose mokyklose ir universitetuose studijavusių asmenų skaičius 1867-1914 metų laikotarpiu. Iš lentelëje pateiktų duomenų matyti, kad kai kurie asmenys stipendijas gavo ilgesnị laiką, tad susidaro tam tikra disproporcija tarp paskirtų stipendijų ir studijavusių asmenų skaičiaus. 
Lietuvos Evangeliku Reformatų Bažnyčios sinodo akademinio lavinimo politikos nuostatos...

\begin{tabular}{|c|c|c|}
\hline Universitetas & Paskirta stipendijų & Studijavo asmenų \\
\hline Dorpatas & 45 & 20 \\
\hline Karaliaučius & 13 & 8 \\
\hline Peterburgas & 36 & 16 \\
\hline Kijevas & 1 & 1 \\
\hline Halè & 1 & 1 \\
\hline Nenurodyta & 1 & 47 \\
\hline Iš viso & 97 & 1 \\
\hline
\end{tabular}

Apibendrinus lenteleje pateiktus duomenis matyti, kad skirtos 97 stipendijos, kuriomis pasinaudojo 47 asmenys. Augančio politinio, kultūrinio ir konfesinio spaudimo sąlygomis tai gana ryškus indèlis ugdant konfesinę religinès mažumos inteligentiją.

\section{Išvados}

Sinodo akademinio lavinimo politikai po 1863-1864 metų sukilimo kilus reikšmingų iššūkių, pamažu, nors ir dejjo pastangas, jis prarado caro valdžios suteiktas iždo stipendijas Dorpato ir Peterburgo universitetuose, kurios buvo skirtos sinodo žiniai kaip kompensacija už dar XIX a. pradžioje suvaržytas studijų galimybes užsienio universitetuose.

Sinodui pavyko sutelkti bažnytinę visuomenę organizuojant tikslines rinkliavas XIX a. pabaigoje - XX a. pradžioje. Surinkti pinigai, atsargi ir nuosekli anksčiau įsteigtų bei naujų sukurtų finansinių fondų administravimo priežiūros politika leido iš gaunamų metinių procentinių palūkanų nuo viso fondo kapitalo sėkmingai pasinaudoti Vilniaus žemės banko paslaugomis, didinant aukštajam mokslui (stipendijoms) skiriamas sumas ir taip sèkmingai kompensuojant valdinių stipendijų praradimą.

Sėkmingu sinodo strateginiu veiksmu, didinant tikslinių lěšų aukštojo mokslo stipendijoms finansuoti apimtį, jo inicijuotas sèkmingai veikiančio kunigaikščių Radvilų fondo kapitalo iš Karaliaučiaus perkèlimas ị Vilnių, gerokai padidintos sinodo finansinès akademinès politikos galimybès.

Dèl procedūrinių trukdžių neatgavus kunigaikštytès Liudvikos Karolinos stipendijų fondo, kuris skirtas trims stipendininkams Karaliaučiuje, tapo aki- 
vaizdu, kad dar likę neišnaudotų rezervų, kuriuos sinodas galèjo ir bandè panaudoti netradiciškai, kūrybiškai, inovatyviai, motyvuodamas tai akademiniu reformatų kilmės merginų lavinimo poreikiu.

Stipendijų skyrimo ir sukauptų lèšų panaudojimo klausimai atskleidè fondų steigejų bei sinodo strateginio mąstymo brandą: fundatoriaus Jono Balčiausko iniciatyva įsteigto fondo nuostatai numate stipendijų skyrimą ne tik evangelikų reformatų, bet ir Romos katalikų tikẻjimo abiejų lyčių asmenims, taip siekiant telkti visuomenę neapsiribojant viena kuria konfesija.

Griežta fiskalinè sinodo politika absolventų atžvilgiu, numačiusi už igytą išsilavinimą grąžinti bažnyčios investuotas lèšas, išskyrus dvasininkus, vèliau - ir kitus bažnyčios tarnautojus, garantavo investicijų i akademinių kadrų rengimą tvarką ir tikslingą lèšų panaudojimą.

Didžiausias, nors ir neiggyvendintas, sinodo akademinès lavinimo politikos strategijos pasiekimas - projektas, kuriuo siekta Dorpato universitete steigti Praktinès teologijos katedrą, kurioje būtų dèstoma lenkų ir lietuvių kalbomis.

\section{Šaltiniai}

Mokslų akademijos biblioteka (MAB). RS F. 40-967. Sinodo memorialai. MAB RS F. 40-1026. Sinodo memorialai.

MAB RS F 40-881/1-3. Sinodo memorialai.

Biržų krašto muziejus „Sèla“(BKM „S“) 18351/6. Kanonai ir memorialai 1867-1918 m.

\section{Literatūra}

Baublys, A. (2006). Lietuvos evangeliku reformatu bažnyčios sinodas; organizacija, bažnytine savivalda ir konfesines inteligentijos formavimas $1795-1830 \mathrm{~m}$. Vilnius: Versus Aureus.

Łukaszewicz, J. (1842). Dzieje kościołów wyznania helweckiego w Litwie, T. 1. Poznań.

Prašmantaitè, A. (1996). Lietuvos evangelikų reformatų bažnyčios valdymas (17951918). Lituanistica, Nr. 1 (25), Vilnius.

Prašmantaitè, A. (1995). Lietuvos evangelikų reformatų švietimo istorijos metmenys. Lietuvos istorijos metraštis. 1996 metai. Vilnius. 
Prašmantaitè, A. (2003). Lietuvos evangelikų bažnyčių istorijos bruožai XIX amžiuje. Lietuvos evangeliku bažnyčios: Istorijos metmenys. Sud. A. Hermanas. Vilnius: Baltos lankos.

Stegner, T. (1993). Pastorzy Królestwa Polskiego na studiach teologicznych w Dorpacie w XIX wieku. Warszawa.

Tyla, A. (1973). Lietuvos jaunimas Tartu universitete 1802-1918 m. Lietuvos TSR MA darbai, A serija, T. 3.

Tyla, A. (1980). Iš Lietuvos kilę Tartu universiteto studentai 1802-1918 m. Lietuvos istorijos metraštis. 1981 metai. Vilnius.

Tyla, A. (1981). Iš Lietuvos kilę Tartu universiteto studentai 1802-1918 m. Lietuvos istorijos metraštis. 1982 metai. Vilnius.

\section{DIE BESTIMMUNGEN DER AKADEMISCHEN \\ BILDUNGSPOLITIK DER SYNODE DER LITAUISCHEN \\ EVANGELISCH-REFORMIERTEN KIRCHE IN JAHREN 1867-1914}

\section{Arūnas Baublys \\ Zusammenfassung}

Die Synodal Beschlüsse der Litauischen Reformierten Kirche deckten auf eine ungewöhnliche Kooperation in der Grundschulausbildung zwischen den Katholiken und den Reformierten. Auf Grund derer, die reformierten Schüler besuchten die katholische Grundschule und umgekehrt, wie auch das der Reformierte Pastor dürfte für die Reformierte Schüler in der katholischer schule konfessionellen Unterricht führen.

Nach dem Aufstand in den Jahren 1863-1864, die Synode, trotz intensiver Bemühungen, auf Grund der unfreundlichen Staatspolitik, langsam verlor die Stipendien des Schatzamtes, die als Kompensation für die eingeschränkten Studienmöglichkeiten an ausländischen Hochschulen, waren an der Universitäten Dorpat und St. Petersburg ermöglicht. 
Der Synode gelang es am Ende des 19. Jahrhunderts, die kirchliche Gesellschaft durch Zielgruppen zu mobilisieren, um die notwendige Geldmitteln zu sammeln und sie in die ziehlmäsig eingerichtete Stiftungen investieren.

Die jährlichen prozentualen Zinsen aus dem gesamten Fondskapital erheblich stärkten die finanzielle Leistungsfähigkeit der Synode im Bereich der Wissenschaftspolitik. Die Synode konnte sie unkonventionell, kreativ und innovativ nutzen.

Der Transfer des Kapitals der Radvilas Studienstiftung aus Königsberg nach Vilnius in Vilnius nach Vilnius war eine erfolgreiche strategische Aktion der Synode.

Die Fragen der Stipendienvergabe und der Verwendung der angesammelten Gelder zeigten die Reife des strategischen Denkens der Stifter und der Synode, besonders im Falle wen das Reglement der vom Stifter Jonas Balčiauskas gegründeten Stiftung, vorsah die Stipendien nicht nur für evangelisch-reformierte aber auch für die katholischen Bewerber der beiden Geschlechter.

Die strikte Fiskalpolitik der Synode gegenüber den Absolventen, garantierte die ordentliche Zuwendung der Mittel.

Die größte, wenn auch nicht realisierte Errungenschaft der bildungspolitischen Strategie der Synode, war das Projekt, zur Einrichtung einer Abteilung für Praktische Theologie an der Universität Dorpat, an der die Unterricht Disziplinen in polnischer und litauischer Sprache gelehrt werden sollten.

Entstehung und Entwicklung der litauischen Intelligenz und ihrer Gruppierungen während des 19. Jh. ist eine der aktuellsten Forschungsthemen der 